\title{
Land Lines
}

\section{The Cheatgrass That Wasn't There}

\section{By Cindy Salo}

65

$t$ looked like the ground was moving; there must have been millions of them. And they were eating every green shoot. It was dark, but I saw some on a light-colored rock. Then I saw 'em everywhere!"

I shivered in the chilly June evening as I listened to the rancher.

"It was warm in January, warmer than it is right now, and I saw the larvae in February," he continued. "I collected some and took them in. The guy said they were army cutworms."

\section{Sleuthing}

I had only been working in Idaho for 5 months when Mike Zielinski called me from the Winnemucca office of the Bureau of Land Management with an all points bulletin (APB) on missing cheatgrass. Although the exotic grass is reviled in the Intermountain West for the fire-carrying fuel it produces, its complete absence was worrisome. Cheatgrass can be the dominant plant on dry sites in northern Nevada, so if it disappears, there is little left to protect the soil from wind and water erosion.

I had spent a day in the field with Mike shortly after I arrived in Boise in January 2003. He hoped I had not gotten busy with projects yet and could look for the missing

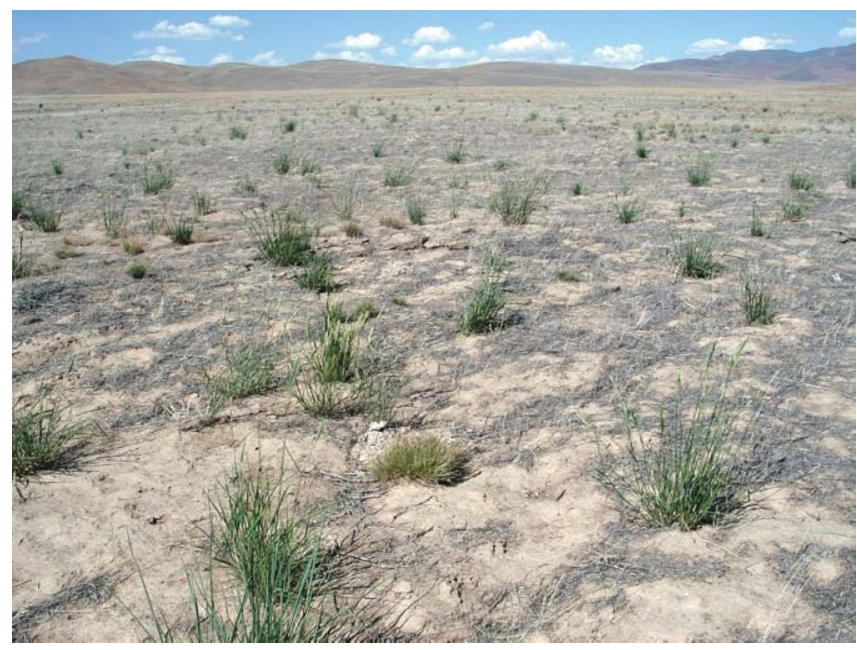

Bare area near Winnemucca, Nevada, in June 2003. Photo: Mike Zielinksi, BLM. cheatgrass. In his APB, Mike described bare areas from a few acres to 10 square miles in size. Not only was there no cheatgrass, there were no weedy mustards. In fact, there were no winter annuals at all. Perennial plants, however, were healthier than usual and seemed to be enjoying the water and nutrients that the annuals would have used. Mike sent me a photo of what looked like a parking lot carpeted with plant litter the color of wet cardboard. A few robust perennial grasses were scattered across it.

A few days later I visited Winnemucca and found areas covered with the gray litter I had seen in the photo and without a single cheatgrass plant. These areas were surrounded by cheatgrass that appeared normal, beginning abruptly at the edges of the die-offs, as though the missing plants had been removed with a cookie cutter. Within the die-offs, small stands of Sandberg bluegrass and scattered globe mallow were growing vigorously. Summer annuals, mostly Atriplex, were thriving on the unused moisture in the soil.

I was stumped. Was a disease responsible? Perhaps a root pathogen killed entire plants. But what would make a disease stop spreading and leave sharp borders around affected areas? And could a pathogen kill plants without leaving any stalks behind? I thought about drought; it is a fact of life in northern Nevada. Could it have been dry enough that the seeds hadn't germinated? Or had the seeds germinated and died later from lack of moisture? I had plenty of ideas-what I needed was evidence.

I stopped at a nearby ranch to ask about suspicious activity in the area and met the rancher who had seen army cutworms (Euxoa auxilialis) devouring plants. Their common name refers to both their habit of marching long distances to find food and to their grey-green uniforms. Army cutworms are native to North America, and they damage introduced crops such as winter wheat, alfalfa, and canola, which produce tender new leaves near the soil in late winter and early spring. However, like any good sleuth, I needed more evidence before I could finger a suspect.

Back in Boise, I called entomologists. Several had noticed adult army cutworm moths the previous fall, but they had only monitored agricultural crops, which had suffered 


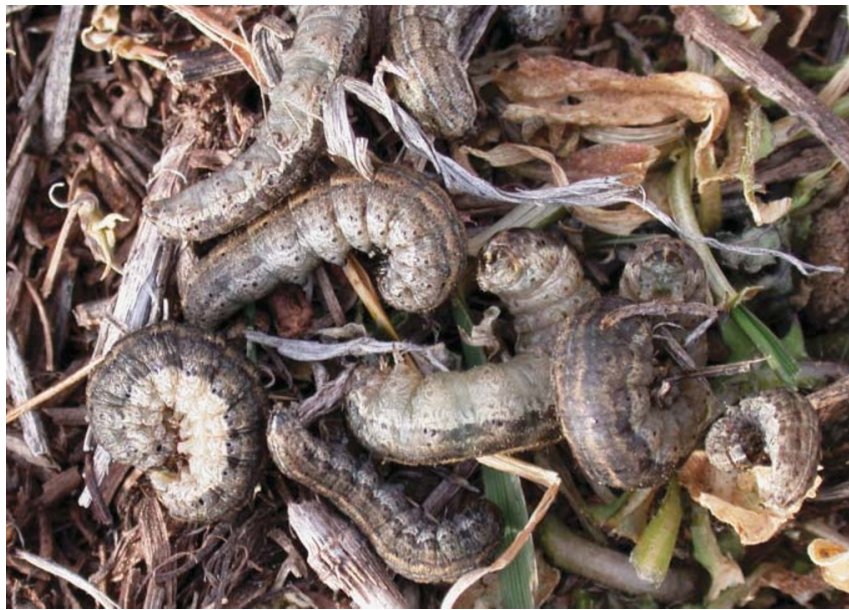

Army cutworm larvae. Photo: Bob Hammon, Colorado State University.

relatively little damage that spring. When I brought up the missing cheatgrass, they were unanimous in exonerating army cutworms: the larvae were not capable of pulling off the heist.

Later in the summer I found a second eyewitness. David Humphrey, a plant ecologist with the SageSTEP program, had seen army cutworms eating cheatgrass in his research plots in northern Utah one evening. Soon a third eyewitness came forward in western Colorado. Bob Hammon, with Colorado State University in Grand Junction, had found 30-40 larvae per square foot in rangelands. The larvae were eating cheatgrass: I had a suspect.

\section{The Suspect Wears a Uniform}

Bob described a "bizarre year" in 2002/2003. At the end of a dry summer he had noticed unusually high numbers of army cutworm moths. Fall rains had germinated a thick crop of cheatgrass and other winter annuals. The rains had also hatched army cutworm eggs that the moths had laid in the soil. An uncharacteristically warm, dry winter provided ideal conditions for the larvae and kept their diseases and parasites at bay.

Although the newly hatched larvae were less than onetenth of an inch long, they had grown into 2-inch-long eating machines by spring. Farmers and ranchers were caught unaware because army cutworms hide in the soil during the day and feed above ground only at night. For many, the first sign of an infestation was missing plants.

"They ate everything except redstem filaree," Bob said. "They marched right by that one."

Local ranchers told Bob that they had seen army cutworms in the late 1970s. But even those who had lived in the area for 60 years had never seen damage on the scale of that in 2003. Although army cutworms are well known as agricultural pests in the US Great Plains and Canada's Prairie Provinces, outbreaks are unusual in the Intermountain West.

Bob, along with Carol Sutherland at New Mexico State University, noted serious army cutworm outbreaks in 2003 from Grand Junction to Monument Valley in Northern Arizona and extending to Albuquerque and eastern New Mexico. In addition, Bob also saw evidence of fungal root diseases. He believes it was likely a combination of army cutworms plus disease that denuded as much as 100,000 acres of rangeland in his area. By the end of the summer, Mike Zielinski estimated that 350,000 acres had been stripped of annuals in northern Nevada.

\section{The Suspect Uses an Alias and Alters Its Appearance}

After army cutworms pupate in the soil in early spring, they emerge as brownish moths and feed on nectar. They are known as miller moths for the flour-like scales shed from their wings when they are trapped in homes and light fixtures.

Miller moths are well known and are loathed on Colorado's Front Range during their semiannual migration between the Great Plains and the Yellowstone area. Although they lack the charisma of monarch butterflies and travel only about half the distance, the moths' journey is impressive. Local media fail to appreciate the remarkable event and use words like "attack," "dive-bomb," and "squadron" to describe it. Mottephobes (those who fear moths) consider relocating or simply vent their frustration on the "I HATE MILLER MOTHS" Facebook page. Locals talk in hushed tones about 1991, when a wet spring on the Front Range provided abundant nectar for the carb-loading moths, which dawdled for weeks on their way to the mountains.

The miller moths' summer at high elevations is no picnic for them, although it is for bears, which eat them by the millions. The moths feed at night and rest in cool talus slopes during the day. Bears, both grizzly and black, can consume 40,000 moths in a day. The 3-month moth season can supply half the annual energy needs of a grizzly bear. The bears' behavior is so well known that it has appeared in at least two books: Cold Case by Stephen White and Blood Lure by Nevada Barr.

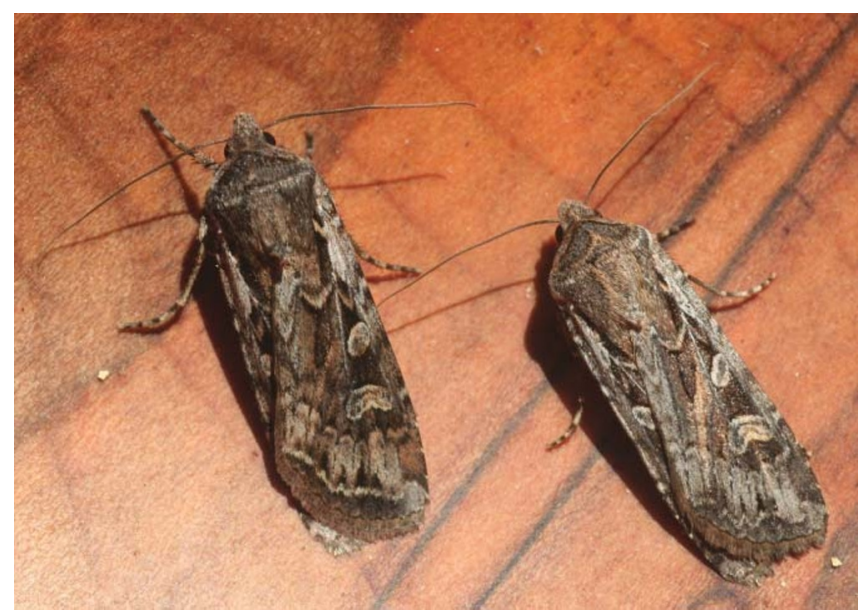

Miller moth. Photo courtesy of Whitney Cranshaw, Colorado State University, http://www.bugwood.org. 
Although we know army cutworms as agricultural pests in the Great Plains and as public nuisances on the Front Range, we know little about their lives in the Intermountain West: How common are they in normal years? What conditions produce outbreaks? How often do outbreaks occur? Where do the adults spend the summer?

\section{Not at All Elementary}

Evaluating the evidence from eyewitnesses - a rancher, a plant ecologist, and two entomologists-plus the circumstantial evidence, I believe that army cutworms were involved in the 2003 cheatgrass die-offs in the Intermountain West. The numerous larvae consumed winter annuals that germinated after fall rains, and the mild, dry winter allowed them to grow rapidly with few diseases. The sharp borders of affected areas may have been formed when larvae migrated en masse to find more suitable food or when they stopped feeding to pupate.

Outbreaks of army cutworms in the Intermountain West are not only unusual; they can be difficult to recognize for many reasons. Although they can have large impacts at both low and high elevations, the larvae themselves are small, especially when young. In addition, their nocturnal habit means that they are visible only when most people are indoors on chilly winter nights.

Rare events, in general, can be difficult to detect. When we hear hoofbeats we think horses, not zebras, and we round up the usual suspects. Range managers are familiar with drought in the West but are less aware of insect or pathogen pests of rangelands. In addition, most entomologists and plant pathologists focus on high-value plants: agricultural crops or ornamentals. Despite the vast areas rangelands cover, few entomologists are working in these extensively managed systems.

We work most closely with people in our own field and, most frequently, with those in our own office or department.
They work on the same things we do; they use approaches we understand; and they talk about things we are interested in. Keeping up with our own field is challenging enough; we do not need to hop the fence to see what others are doing in theirs.

Finally, answers in rangeland ecology and management are rarely simple. The regional cheatgrass die-off of 2003 was likely the result of both extraordinarily high numbers of army cutworms plus one or more diseases. Although Bob Hammon has continued to see locally damaging populations of army cutworms, another widespread outbreak has not occurred. However, the cheatgrass die-offs have continued in northern Nevada.

\section{The Coffeehouse Solution}

Many people responded to Mike Zielinski's APB on cheatgrass before he retired in February 2011. Stephen Boyte and his colleagues at the US Geological Survey's EROS Data Center are using remote sensing techniques to map the die-offs over time. Tye Morgan and Bob Blank, with the Agricultural Research Service in Reno, are investigating the bare areas on the ground.

In Where Good Ideas Come From, Steven Johnson describes "cross disciplinary coffee houses" as an ideal approach to solving complex problems. These are places where people from different fields share and challenge each others' ideas, borrow them, add to them, and modify them, until new understanding and solutions develop.

The mystery of "the cheatgrass that wasn't there" is far from solved; it may take a task force to crack the case. Let's meet at the coffeehouse and talk about it.

Cindy Salo is a freelance plant ecologist. She works and writes in Boise, ID, USA, CindySalo@SageEcoSci.com 